\title{
Work and Families in Times of Crisis: The Case of Israel in the Coronavirus Outbreak
}

Coronavirus and inequality brief No. 202005_02

Efrat Herzberg-Druker, Tali Kristal, and Meir Yaish

University of Haifa

\section{Introduction}

The cumulating evidence on the consequences of the economic crisis following the coronavirus pandemic indicates that this crisis hits the hardest the most vulnerable in society (Bol, 2020; Bernardi, 2020; Recchi et al., 2020; Kristal \& Yaish, 2020). It follows that inequality between families of different structures and with different socioeconomic characteristics will increase as a result of this crisis. Just as important, since this crisis hit women disproportionally (Kristal \&Yaish, 2020), it is likely to also affect inequality within the family. The shutdown of the economy, coupled with the closure of the educational system and restrictions on movements outside the home, resulted in increasing demand for unpaid work (care and housework) at home. This new situation may have also contributed to affecting the gender division of unpaid work within families. The following questions, thus, lie at the heart of this report:

1. To what extent does the coronavirus pandemic and the economic crisis following it affect inequality between families?

2. To what extent did the coronavirus pandemic and the economic crisis following it affect inequality within the family? Particularly:

a. Has the prevailing gender inequality in the division of unpaid labor decreased as fathers invest more time in housework and care due to the rise in demand for unpaid work and the fall in paid labor outside the household? Or,

b. Has the increase in demand for housework and care satisfied mainly by mothers, increased the level of inequality in unpaid labor due to the outbreak of coronavirus pandemic?

\section{The Israeli Case}

Families in Israel are strongly attached to the labor markets, regardless of the presence of young children, and have increased their participation and hours invested in paid employment in recent decades (Herzberg-Druker \& Stier, 2019; Stier \& Herzberg, 
2013). Consequently, a large share of Israeli families are fulltime dual-earner families (about 39\% of all couple-headed households in 2008). Despite this, unpaid labor at home is still gendered, and a large share of housework and care is under women's responsibilities (Mandel \& Birgier, 2016). This is all true in normal times. But, is it still the case in the troubled times that follow the outbreak of the coronavirus pandemic?

Israel reacted quickly to the spread of the virus and by the middle of March, closed its educational system following the closure of many workplaces. At the same time, many employees moved to remote employment from home (about $40 \%$ in our data). Recent research in Israel shows that about $35 \%$ of those employed in the first week of March were not employed by the end of April, most of them (30\%) sent to unpaid leave (Kristal \& Yaish 2020). As most members of the family were forced to spend a large part of their time together at home, the dynamics and behavior of the family has had to change and adapt in many ways. This brief offers a first examination into these new dynamics.

\section{Empirical Strategy}

Data for this study are based on the first wave of a longitudinal survey of 2,040 adult Israeli men and women (age 18+), Jews and Arabs, who were employed or selfemployed in the first week of March, prior to the lockdown of the economy. ${ }^{1}$ The first wave includes information on employment and job characteristics of Israeli households in the first week of March (before the economic downturn) and in the last week of April (after the economy was shut down, but before it was reopened). The current analysis focuses on couples with children under 18 in this first wave. In this brief, then, we analyze data on 940 Israeli couples with children under 18 who reside in the same household.

\footnotetext{
${ }^{1}$ For more information on the data see (Kristal \& Yaish, 2020)
} 


\section{Inequality between Families}

To what extent have families changed their employment status due to the coronavirus outbreak?

Figure 1 shows how the economic shutdown due to the spread of coronavirus in Israel has affected the employment status of Israeli families. We identify, on the x-axis, five family types based on the employment status of the heads of households in March, prior to the spread of the coronavirus in Israel: i) dual earners; ii) men single earners; iii) women single earners; iv) men single households, and v) women single households. The bars in these graphs indicate, for each family type, the relative share of each employment status in April, at the peak of the coronavirus crisis in Israel. ${ }^{2}$

Thus, for example, only 58\% of dual-earner families in the first week of March remained dual-earner families by the peak of the crisis in April. Some 33\% of these families, moreover, lost one earner (21\% become men-single earner families and $12 \%$ became women-single earner families), and in $9 \%$ of the cases, both spouses lost their employment (whether they were forced to take an unpaid leave or were laid off).

Among men single-earner families at the beginning of March, 29\% lost their only earner by the end of April. Women single-earner families were affected by the crisis even more severely. In these families, $38 \%$ of the earners lost their employment and subsequently their only source of income. Similarly, amid households with only a single parent, $29 \%$ of the men and $40 \%$ of the women lost their jobs by April. Within the Israeli family, then, women seemingly had to absorb the larger share of the shock caused by the coronavirus pandemic. These findings add another perspective on the precarious position of women relative to men in Israel's economy (see, Kristal \& Yaish, 2020).

Interestingly, the economic hardship following the coronavirus crisis pushed some $12 \%$ of the women in what used to be men-single earner families in March into the paid economy by April. The equivalent proportion for men is lower than half of this figure, estimated in our data to be as low as 5\%. This indicates that in times of crisis, when the only earners in an Israeli family lost employment, more Israeli women than men took responsibilities also for the families' economic wellbeing.

\footnotetext{
2 This typology of employment status is based on how many earners contribute to the family income from employment (for the employees) and business (for the self-employed).
} 
Figure 1: Changes in family employment status due to the coronavirus crisis in Israel. Couple and single-headed households with children under 18 ( $\mathrm{N}=940)$

- Both employed in April $\square$ Men employed in April $\square$ Women employed in April $\square$ Not employed in April

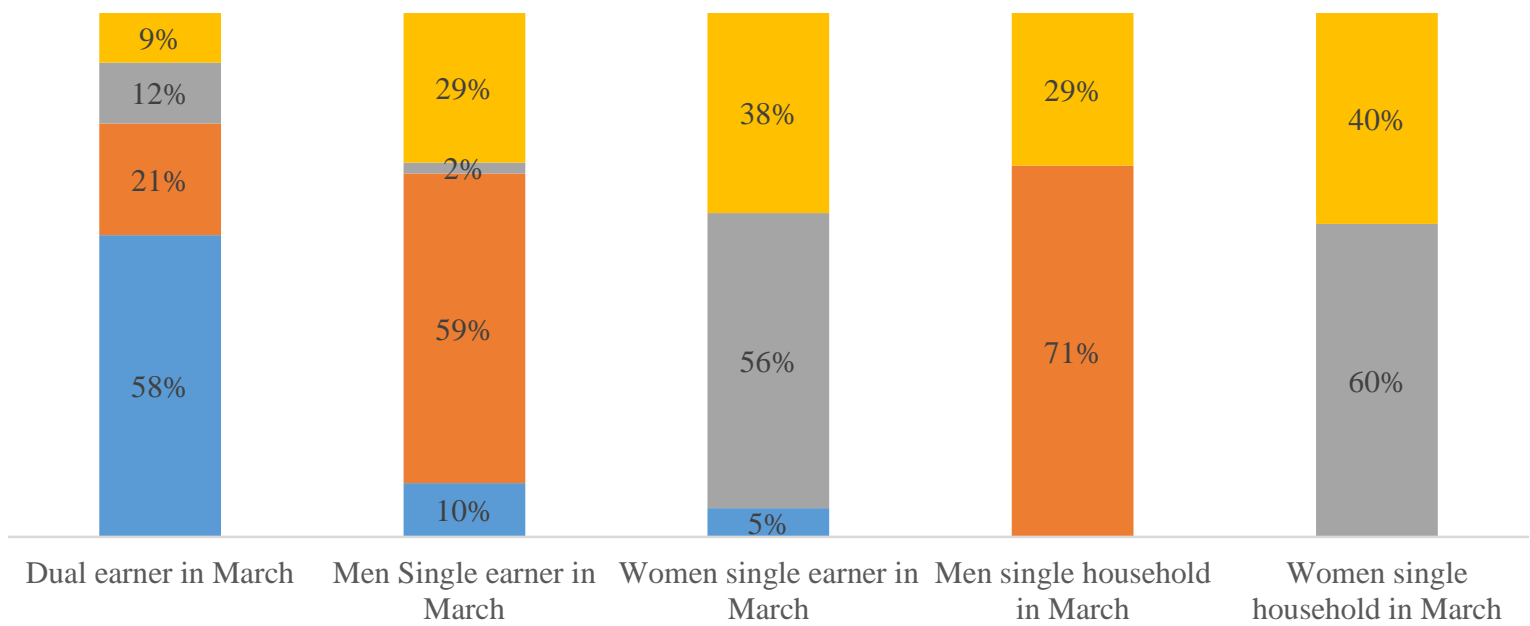

Was this change in the family employment status similar across the entire income distribution? If families, particularly dual-earner families, at the lower end of the income distribution lost more earners in March than those at the upper end of the income distribution, we should expect an increase in income inequality between families.

To examine this, we record in Figure 2 changes in employment status of dual-earner families in March due to the coronavirus crisis, by incomes quintiles. It shows that the impact of the crisis was more severe at the lower end of the income distribution. While in the lowest income quintile only $41 \%$ of dual-earner couples in March maintained their employment status by April, in the highest income quintile about $76 \%$ of the families maintained their dual-earner status. Moreover, $21 \%$ of the dualearner families in March within the lowest income quintile lost their jobs or businesses completely by April. This figure is then matched by only $2 \%$ of the dualearner families in March at the highest income quintile that lost their sources of income by April. Families that had lower incomes before the crisis were affected the most, suggesting that income inequality between families has increased due to the coronavirus crisis. Importantly, Figure 2 also indicates that this increase in income inequality is driven by the deterioration in the economic conditions of families in the 
bottom of the earnings distribution in March—suggesting that the weak families are in danger of becoming even weaker.

Figure 2: Changes in family employment status in April by family income quintiles in March, dual-earner (in March) couples with children under 18 (N=940)

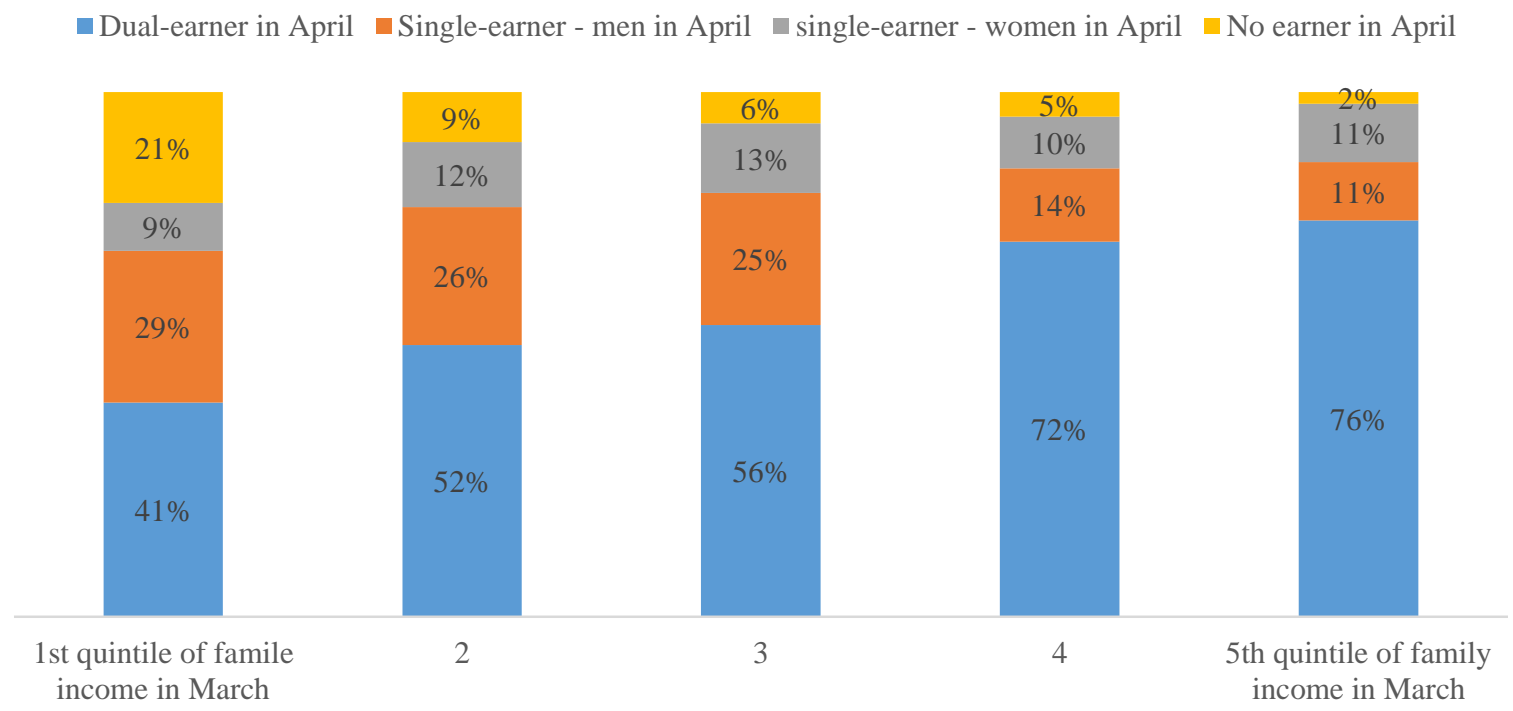

Dual-earner families throughout the crisis: changes in income and employment pattern due to coronavirus crisis

The impact of the crisis was not only manifested in layoffs and business terminations but also in changes in working hours. To examine this, we focus next on the dual earners in March who remained dual-earners also in April. Figure 3 reveals that among these selected families, there was an increase of $110 \%$ in the share of families where both spouses work part time (less than 35 hours per week), coupled with a decrease of $45 \%$ in the share of families with two fulltime earners. Finally, the relative share of women working full time when their spouse work only part time has increased dramatically (by 47\%) due to the coronavirus crisis. The equivalent figure for men has barely changed in the same period $(-2 \%)$. These interesting results suggest, again, that women took more economic responsibilities within the family due to the coronavirus crisis. 
Figure 3: Changes in patterns of employment between March and April among dual earner-households with children under 18 who stayed dual earners during the coronavirus crisis $(\mathrm{N}=395)$

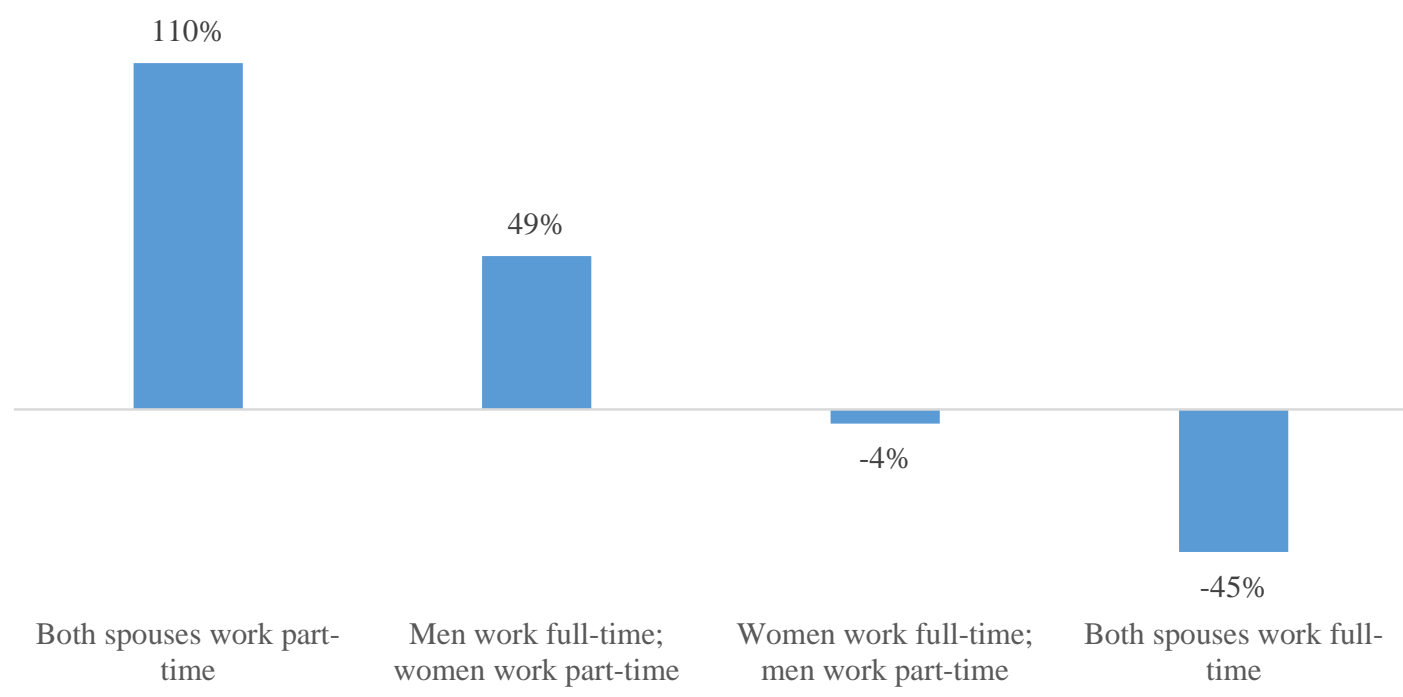

Finally, when we examine how the relative income of the two spouses has changed due to the coronavirus crisis, our data show that families in which the men earn more than the women is still the dominant pattern among dual-earner couples in Israel. Nevertheless, we also find an increase of about $6 \%$ in families in which women earn more than men.

In sum, patterns of employment and income within dual-earner couples with children have changed as a result of the coronavirus crisis. Whether or not these changes also impinge on the inequalities within families in the division of housework and careparticularly as the demand for these have increased - is the focus of the next section.

\section{Inequality within Families (dual earners throughout only)}

The tradeoff between family and work is a topic fueling public and academic debates. The consensus in this field is that although women have increased their employment and labor market outcomes, their share of housework and care is still substantially higher than men's (Perry-Jenkins \& Gerstel, 2020). Also Israeli women in dual-earner families spend almost twice as much time as men to housework alone (Mandel \& Birgier, 2016). Henceforth, in the second part of this report we study the consequences of the coronavirus pandemic for inequality within families in Israel after the shutdown of the schools and the economy. 
To what extent do families invest more time on housework and care due to the coronavirus crisis?

Alongside the substantial loss of employment and consequently of income among families, demand for unpaid work at home has increased due to school closures and the increase in hours that all the family members spend inside their homes. Dualearner families with children are of great interest in this unique situation, because both spouses stayed employed while demand for unpaid work at home has increased. In the light of these changes, and also changes in the employment patterns within these families discussed earlier, this part of the brief examines the extent to which the gender division of unpaid work has changed in these families.

We begin by examining the level of the gender inequality in unpaid work before and after the coronavirus crisis. Figure 4 shows, unsurprisingly, that women take the lion's share of housework (including cleaning, cooking, laundry and grocery shopping) and care (only for children), before and after the coronavirus outbreak and regardless of having young children. Thus, for example, women's share in unpaid work ranges from $58 \%$ in housework to $64 \%$ in child care, with no statistically significant differences between March and April. In term of weekly hours, in March women, on average, spent 16.6 hours on housework and 29.0 on child care. In April, on average, the numbers are 18.7 and 34.1.

Figure 4: Share of women's unpaid labor in March and April, dual-earner households with children under $18(\mathrm{~N}=395)$

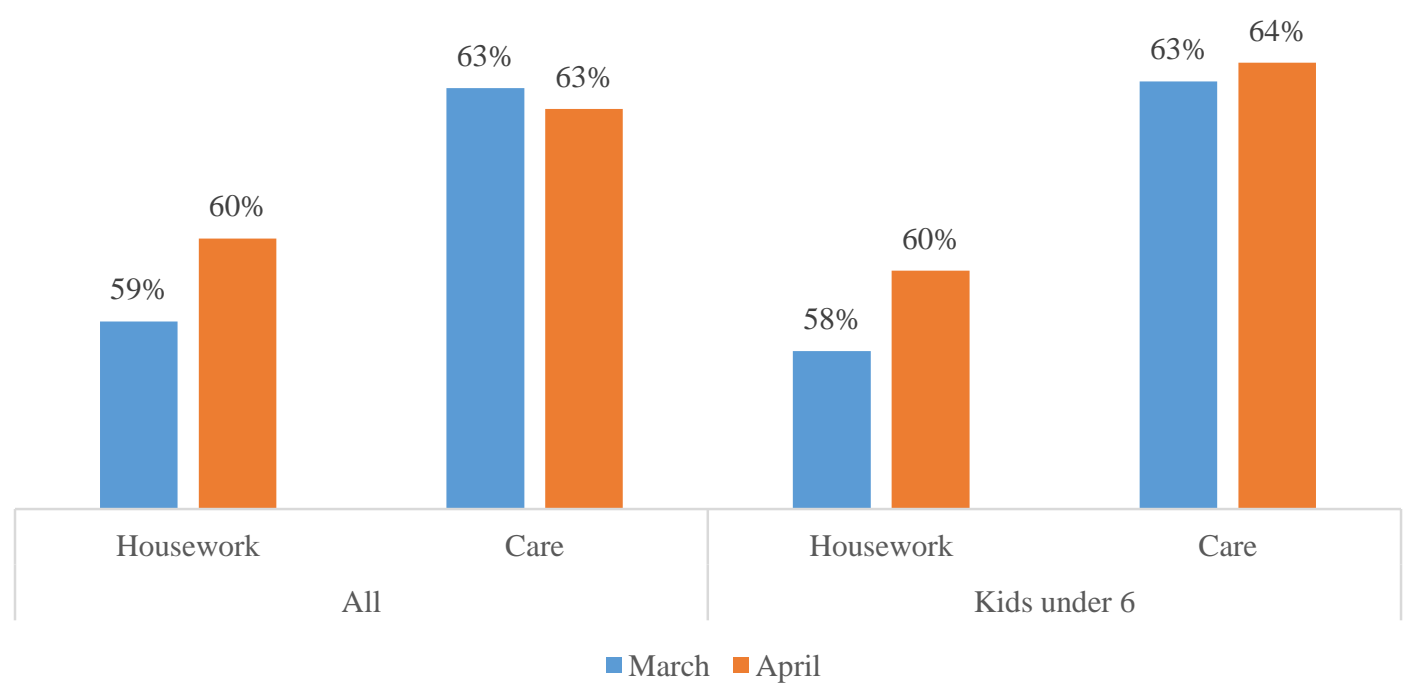


Figure 5 presents changes in number of hours devoted to housework and care among dual-earner couples as a result of the coronavirus outbreak. As expected, the number of hours the couple invested in housework has increased by about two hours due to the coronavirus crisis. More significant, however, is the sharp increase in number of hours devoted to care: additional 9 hours per week overall, and 13 hours per week for families with young children.

Figure 5: Changes in number of unpaid work hours (housework and care) between March and April by gender among dual earner households with children $\left(\mathrm{N}_{\text {all }}=395 ; \mathrm{N}_{\text {under6 }}=281\right)$.

$$
\text { Men Women }
$$

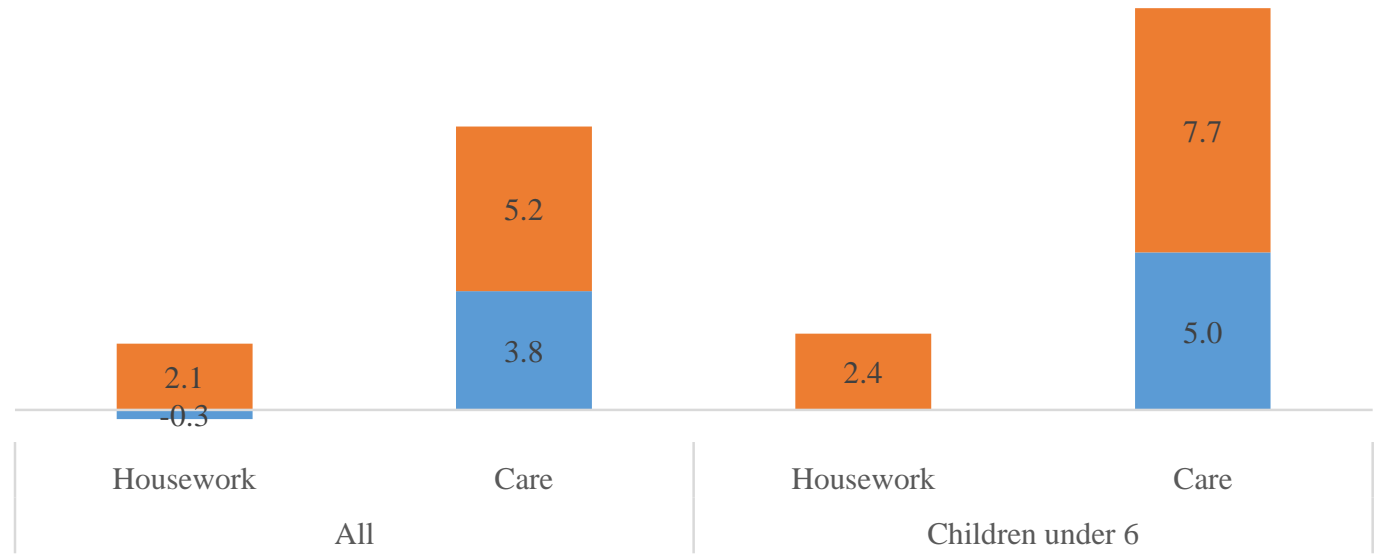

Supporting the thesis that the level of inequality in unpaid labor has increased due to the coronavirus crisis, is the increase in hours not equally shared by both spouseseven though both men and women remained employed in April. Thus, for example, women have increased their housework by about two hours per week, while men have decreased their housework load slightly. That is, not only that men did not increase their participation in housework, but they decreased it. These differences in the number of weekly housework hours are not surprising since the housework activities in which men usually participate are housework activities that are related to activities outside the home, such as grocery shopping — which increased only slightly compared to "women's" housework activities, such as cleaning and cooking.

Moving to care work, we see in Figure 5 an increase of about 9 hours per week, with men's increased hours by 3.8 and women's by 5.2 hours. That is, women carry again the lion's share of the demand for care work due to the coronavirus crisis. Although 
men have increased their care responsibilities, the gender division in unpaid work has not become more egalitarian due to the coronavirus crisis. Moreover, it seems that the increase in the care responsibilities by men was offset by a decrease in housework. Finally, as the right panel in Figure 5 reveals, the change in weekly unpaid work hours among dual-earner families with young children (6 and under) is largely similar to the overall, but at a somewhat higher level. Thus, the total hours of care work have increased by 12.7 hours (compared to 9 for all), but the women's share in this increase remained at about $60 \%$ for all and for families with young children $(7.7 / 12.7=0.61$; $5.2 / 9=0.58)$.

To what extent are employment and income characteristics of couples associated with different levels of unpaid labor?

We next examine the extent to which the relative income of couples is related to the different division of housework and care. Figure 6 presents changes in hours of housework and care due to the coronavirus outbreak, this time by different configurations of the spouses' relative income.

Figure 6: Changes in number of unpaid work hours (housework and care) between March and April by gender and couples' relative income $(\mathrm{N}=395)$

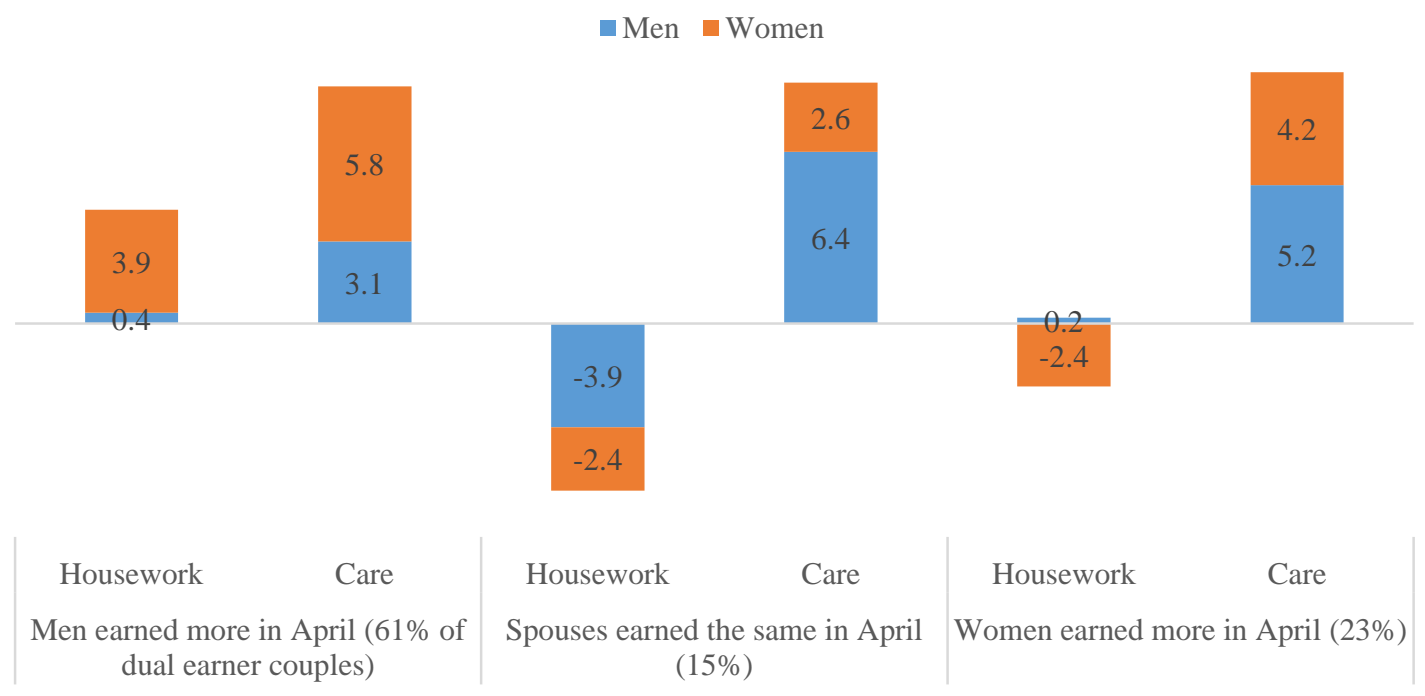

First, we can see that the demand for unpaid care work has increased across all configurations of spouses' relative income. Second, demand for housework has increased too, but only in families were women earn less than men. In these families, women have increased their housework by about 3.9 hours-equivalent to about $91 \%$ 
of the increase in housework $(3.9 / 4.3=91 \%)$ — and care work by about 5.8 hours, which equals about $65 \%$ of the increase in care work $(5.8 / 8.9=65 \%)$.

Nonetheless, our findings leave also some room for optimism. This is mainly because we see that among families in which men and women earn about the same, men took a greater share of the burden of care work $(6.4 / 9=71 \%)$. A similar pattern is found among families in which women earn more than men, where we see that men took on more than half of the increase in care work $(5.2 / 9.4=55 \%)$.

As working hours of spouses within the family have changed due to the outbreak of coronavirus (Figure 3), the next analysis examines whether this change has also consequences for the division of unpaid work in the family. Figure 7 shows that most of the demand for unpaid work was for caring. In this regard, we can see that in families in which men worked full time and women worked part time only women have increased their load. This family type, however, is the most dominant one, accounting for about $34 \%$ of all dual-earner families, and thus the overall contribution of men to the demand for care is less encouraging. In this family type, moreover, only women offset the growing demand for care work and increased their load by 10.31 weekly hours. Men in these families did not increase their load - and even somewhat decreased it (-0.11 hours).

Figure 7: Changes in number of unpaid work hours (housework and care) between March and April by gender and couples' employment patterns $(\mathrm{N}=395)$

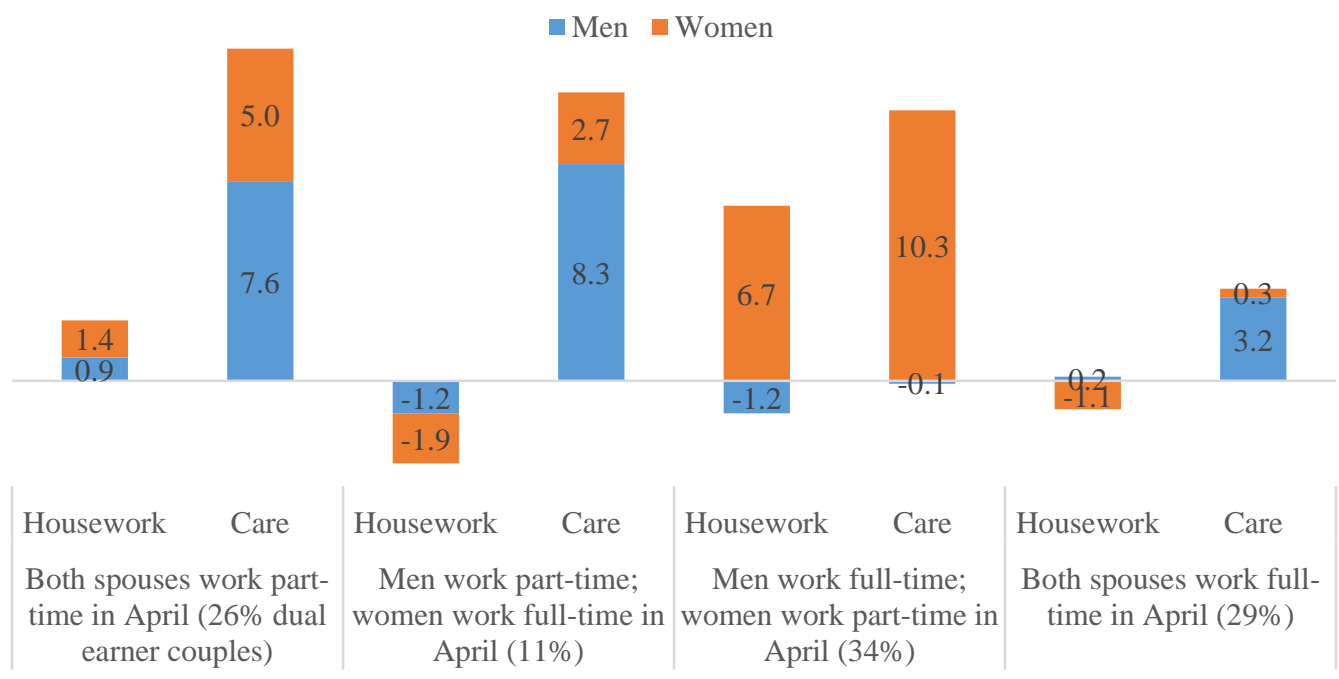

In all other family types men have increased their weekly care work more than their wives. Among families in which both spouses worked part time in April (26\% of 
dual-earner families) men have increased their weekly care work by 7.6 hours compared to only 5 hours increased by women. A similar pattern characterizes families in which men work part time and women work fulltime (11\% of dual-earner couples). Accordingly, men in these families have increased their weekly care hours by 8.25 compared to only 2.73 hours by women. As these findings are encouraging and a move towards increasing equality in the gender division of unpaid work within the family, it is important to keep in mind that more than a third of all dual-earner families in March and in April are families in which men worked fulltime and women worked part time.

\section{Conclusions}

This report focuses on two aspects of inequality and families. We began by asking about inequality between families mostly based on employment status and found that due to the coronavirus outbreak, a substantial share of Israeli families has lost their employment. The short term effect of the crisis affected the bottom of the income distribution more severely than families in the upper end of the curve, as more families that earn less to begin with (such as dual-earner families in the lowest quintile and women single headed households), have lost some or all of their employment, that is their incomes. Although income inequality was not measured directly in this report, our findings suggest that it has increased due to the changes in employment status of families.

Following the between families' inequality, our second question was about inequality within families. We asked what happened to gender division of unpaid work among dual-earner couples due to the coronavirus crisis. On the one hand, our findings suggest some room for optimism since men have increased their number of care hours (but not housework hours) in times of need as was found in two other preliminary researches in Canada and the US (Carlson et al., 2020; Shafer et al., 2020). On the other hand, our findings also highlight that gender division of housework is still substantial. On average, men do not change their behavior in this aspect although housework needs have increased. We found that when taking into account relative incomes of spouses as well as employment patterns of couples in April, there is also some room for optimism regarding the care responsibilities of some couples - the non- 
traditional couples in terms of relative income and couples in which both spouses work part time and couples in which men work part time and women work full time. However, though the share of traditional couples (62\% and 61\% in March and April respectively) is the common type and the share of couples in which men work full time and women work part time increased (23\% in March and 34\% in April), in most families the gender division of unpaid work is still substantial and unequal. It is important to highlight here that we cannot examine the extent to which the decrease in women's number of work hours is due to employers' decisions to reduce economic activities in their work places, or if the change in their work hours was a reaction to the growing demand for unpaid care work at home due to the closure of the educational system.

As these words are written, Israel has managed not only to 'flatten the pandemic curve' but to also ease most of the restrictions on the economy and schools. Therefore, as the second wave of data collection is planned to take place in the next couple of months we will be able to examine the extent to which changes in the behavior of men that we have identified above are the beginning of an equalization process in the gender division of unpaid work or whether they have only 'stepped in' temporarily to meet the growing demand. 


\section{References}

Bernardi, F. (2020). Pandemics...the great leveler? EUIdeas, Evidence-driven contributions on social, political, legal, and economic issues. https://euideas.eui.eu/2020/04/28/pandemics-the-great-leveler/.

Bol, T. (2020). Inequality in homeschooling during the Corona crisis in the Netherlands. First results from the LISS Panel. https://doi.org/10.31235/osf.io/hf32q

Carlson, D. L., Petts, R., \& Pepin, J. R. (2020). US Couples' Divisions of Housework and Childcare during COVID-19 Pandemic [Preprint]. SocArXiv. https://doi.org/10.31235/osf.io/jy8fn

Herzberg-Druker, E., \& Stier, H. (2019). Family matters: The contribution of households' educational and employment composition to income inequality. Social Science Research, 82, 221-239. https://doi.org/10.1016/j.ssresearch.2019.04.012

Kristal, T., \& Yaish, M. (2020). Does the coronavirus pandemic level gender inequality curve? (It doesn't). Research in Social Stratification and Mobility, 100520. https://doi.org/10.1016/j.rssm.2020.100520

Mandel, H., \& Birgier, D. P. (2016). The Gender Revolution in Israel: Progress and Stagnation. In N. Khattab, S. Miaari, \& H. Stier (Eds.), Socioeconomic Inequality in Israel (pp. 153-184). Palgrave Macmillan US. https://doi.org/10.1057/9781137544810_8

Perry-Jenkins, M., \& Gerstel, N. (2020). Work and Family in the Second Decade of the 21st Century. Journal of Marriage and Family, 82(1), 420-453. https://doi.org/10.1111/jomf.12636

Recchi, E., Ferragina, E., Helmeid, E., Pauly, S., Safi, M., Sauger, N., \& Schradie. J. (2020). The "Eye of the Hurricane" Paradox: An Unexpected and Unequal Rise of Well-Being During the Covid-19 Lockdown in France. Research in Social Stratification and Mobility, 100508. https://doi.org/10.1016/j.rssm.2020.100508.

Shafer, K., Milkie, M., \& Scheibling, C. (2020). The Division of Labour Before \&amp; During the COVID-19 Pandemic in Canada [Preprint]. SocArXiv. https://doi.org/10.31235/osf.io/24j87

Stier, H., \& Herzberg, E. (2013). Women in the labor force: The impact of education on employment patterns and wages. In State of the Nation Report-Society, Economy and Policy 2013, Taub Center for Social Policy Studies in Israel (2013) (p. 33). 